in size because all the staff were permanent. Like other witnesses, the CBI was all in favour of making it easier to transfer from establishments to industry, and said that "a real effort should be made to simplify the transfer".

The CBI was also critical of the procurement of defence equipment. The witnesses were particularly eritical of the spccification written for a transport aircraft, under the code number 681 . This had been so stiff that no British manufacturers had been able to produce a low price. As a result, according to the CBI, the RAF had then gone to the United States, and bought an aireraft which fulfilled none of the requirements. But the burden of the argument was summed up by Sir Denning himself- "Research is better done in industry because it is done better there," he said. Coming from the chairman of one of Britain's most succossful companies, the statement carried weight.

\section{Sloan on Science}

Since 1934 the Alfred P. Sloan Foundation has been a major supporter of projects in the fields of seience research and science policy, engineering, education and cancer research. In the 1967 annual report, Mr Everett Case, president of the foundation, stresses that "the general-purpose foundation has asserted that its role is not the alleviation of human suffering or want, but rather the support and acceleration of the search for new knowledge which may expose their root causes". In spite of the general and increasing alarm, especially during the past year, over the growing racial and urban problems facing the United States, Mr Case considers that such organizations as the Sloan Foundation must not alter their programmes with every "change of the wind". "In any stampede which threatened the healthy diversity of major foundation programs, the social gains would be minimal as compared to the probable losses."

But this is not to say that the foundation is oblivious to the present social problems; it is, in fact, supporting a number of programmes designed to help Negro colleges and students. The foundation has already contributed one million dollars and has authorized another million for matched-grant offers to a number of southern Negro colleges-23 in 1965, 30 in 1967--which are members of the Cooperative College Development Program. The programme is an attempt to encourage the colleges' fund-raising ability, both from alumni and the community, and from industry, foundations and government. Since the programme began, all twenty-three colleges have designated development officers and "efforts are now under way to involve academic deans and faculty more closely in planning for the total development, academic as well as financial, of each institution". The foundation is also helping to support the School of Business Administration at Atlanta University, the only Negro graduate business school in the United. States, and National Medical Fellowships, Inc, which assists qualified Negro medical students.

In more traditional areas, the foundation continued its large support - $\$ 1.4$ million a year —of basic research and the soience and engineering departments in a number of universities. The foundation is becoming more interested in the social problems of science-how citizens may be well enough informed to make, or at least understand, science policy decisions, and "the social, economic and human consequences of the increasing domination of modern life by science and technology". In this field money was allocated to the California Institute of Technology to develop a crossdepartmental programme, to Harvard for a new elementary physies course, and to the National Academy of Sciences.

\section{Parliament in Britain}

\section{Fulton Report}

Mr Hanoln Wuson, the Prime Minister, made a statement to the House of Commons on the recommendations of the Fulton Committee (Nature, June 29, 1968). While the report is still being studied by the Government, Mr Wilson stated that, broadly speaking, it accepted the analysis and the main recommendations and was prepared to embark on the process of reform outlined by the committee.

$\mathrm{Mr}$ Wilson noted that the Fulton Report was part of a larger attempt to modernize Britain's basic institutions; the recommendations of the Donovan Report on Trade Unions and Employers' Associations are still being discussed and the two commissions on local government-Lord Redcliffe-Maud's on England and Wales and Lord Wheatley's on Scotland-will provide long over-due reform in an area that is little changed since the late nincteenth century.

The three main points accepted by the Government were the establishment of a new Civil Service Department, the setting up of a Civil Service College and the abolition of classes within the Civil Service so that movement throughout the service will be unimpeded. A subsidiary point applauded by the Prime Minister was the committee's wish for easy two-way movement between the service and other fields. Concomitant with the establishment of a new Civil Service Department, the report recommended that the now department be under the control of the Prime Minister, who would delegate day-to-day responsibility to a "Nondepartmental Minister. . . who is also a member of the Cabinet". Mr Wilson announced that he was appointing Lord Shackleton, the Paymaster General, to take up this position and to supervise the setting up of the new department.

In the question period which followed, the Prime Minister elaborated on interchange between the Civil Service and people and positions outside the service. $\mathrm{He}$ anticipated that the training college would be open to a considerable number other than civil servants and pointed out that the report also envisaged a regular flow of recruits on a temporary basis from private and public industry, the universities, professions, local government, finance and commerce, and a parallel flow of career civil servants to industry and local government, bearing in mind the problems that will be raised concerning transferability of pensions. (Statement, June 26.)

\section{Violence on Television}

Mrs Shirley Willtams, Secretary of State for Education and Science, stated that the Social Science Research Council would be prepared to consider any proposals for a research project on the long term behavioural effect on viewers of violence in television programmes, but added that no such project was being considered at present. (Written answer, June 27.) 